\title{
Factors that affect sustainable construction waste management efforts at site
}

\author{
A. S. Ya’cob, W. N. A. Abdullah Zawawi, M. H. Isa \& I. Othman \\ Department of Civil Engineering, \\ Universiti Teknologi PETRONAS, Malaysia
}

\begin{abstract}
Approximately 40 per cent of waste component in the world is generated from the construction and demolition of structures. Guidelines on sustainable Construction Waste Management (CWM) practice have already been published by the Construction Industry Development Board (CIDB). However, the waste amount generated is still high. Consequently, in order to identify the factors that affect SCWM efforts at site, 95 questionnaires were sent to construction players and 30 responses were received. The respondents admitted that awareness in managing construction waste sustainably among them is low and the results suggested that the degree of training and education should be increased in order to emphasize the importance and benefit of SCWM practice at site. In addition, the respondents agree that a lack of law enforcement from the Government led to the contractor not following the standard.

Keywords: construction and demolition of structure, Construction Waste a nd Sustainable Construction Waste Management.
\end{abstract}

\section{Introduction}

Approximately 40 per cent of waste component in the world were generated from construction and demolition of structures (Kulatanga et al. [1]). Constant trend of high amount of construction and demolition (C and D) waste produced has given a negative impact to the environment. For the past years, most of the construction wastes were disposed at landfill and other construction materials like timber and paper-based products were burnt on site (Ya'cob et al. [2]). This issue will keep continuing unless effective measures are taken seriously. In Malaysia, data on the present structure of construction waste is still unavailable 
(Begum et al. [3]). At the same time, researchers need to develop effective approaches that aim for minimizing construction waste. Thus, researches to study and evaluate the level of current construction waste management practice in Malaysia have become an urgent need (Yacob et al. [2]).

Guideline on sustainable Construction Waste Management (CWM) practice is already published by the Construction Industry Development Board (CIDB). However, the waste amount generated is still high. In Hong Kong, a number of strategies have been employed under government initiatives to help reduce waste generation, namely: (i) enactment of the Waste Disposal Ordinance; (ii) issuance of a white paper for a comprehensive 10-yr plan to reduce construction waste; (iii) launching of a green manager scheme; (iv) issuance of a practical note on the use of recycled aggregate; (v) commission a pilot recycling plant to supply recycled aggregate to public projects; (vi) issuance of a circular on waste management; and (vii) implementation of a charge for waste dumping. The regulations and methods implemented by the Hong Kong government is aiming at minimizing waste production, and thus improving the environment (Tam [4]).

The purpose of this paper is to identify the significant factors that affect sustainable Construction Waste Management effort at a site in Malaysia.

\section{Literature review}

There are many studies have been conducted all over the world to address the importance of sustainable CWM at site. Ya'cob et al. [2] had briefly described on Effective Waste Management Practice at Construction Site. There are five items should be emphasized by contractors in managing construction waste at site which include begin with waste segregation, identification of cause of waste, reuse and recycling of waste and cost-benefit analysis application to evaluate the profit gain from reusing and recycling of waste. All of these items are important in order to achieve a sustainable construction waste management at site (Ya'cob et al. [2]).

\subsection{Perception of construction players towards sustainable CWM at site}

Sustainable Waste Management Plans (SWMPs) is another approach of managing construction waste sustainably. Based on a study that investigates the barriers of SWMPs at construction site, it was found that 57 per cent of contractors stated that SWMPs will give implication on the cost of project as the main reason, whereas 43 per cent identified the lack of available information and guidance, incentives and practical tools about SWMPs as the main barrier (Papargyropolou et al. [5]). In a nutshell, the main factors preventing contractors from using SWMPs in Malaysia are the respondent believe that appropriate construction waste management practices reduce their profits and promotion and encouragement by the Government and CIDB is still lacking (Papargyropolou et al. [5]). Another study conducted by Abdullah [6] also addresses the same result. Cost implication was ranked as the most main barriers and lack of environmental education and awareness was ranked after Abdullah [6]. Whilst, results from 
another study conducted by Tam [4] show that, "Low financial incentive" and "Increase in overhead cost" are considered as the major burdens in implementing the WMP method (Tam [4]).

\subsection{Effect of poor waste management}

Waste management at site begins with housekeeping and waste segregation. Housekeeping should be a common practice by all contractors as it is part of all project agreement. According to Saskatchewan Construction Safety Association (SCSA) [7], housekeeping is the main problem at construction site. Many accidental and near misses occur as a result of poor housekeeping. Efficiency and morale at the worksite can be greatly improved if positive attitude and proper care is taken towards housekeeping. Housekeeping is not just cleaning up waste; it provides a complete basis on which to strengthen overall practices at your construction site. Without a good housekeeping practice, chances for slip, trips, and more serious accident at site are high. SCSA had listed a few examples of effect of poor housekeeping that can be seen as follows:

- Tools not properly stored and are more easily damage;

- Time is wasted cleaning up or looking for items in the mess;

- Emergency exits and access to fire extinguisher can be blocked;

- Sharp objects, wires, greases, scrap materials and lumber with protruding nails area among the typical workplace hazards that will affect the workers safety.

\section{Methodology}

The primary data required for this study was collected through indoor method namely questionnaire survey. In order to meet the research objective, a close ended questionnaire was designed to gain feedback from the constructions players. In this study, the respondents are building contractors, Local authorities, developers, consultant, architect, and Government sectors.

\subsection{Questionnaire survey outline}

A two-page close-ended questionnaire was developed to meet the research objective. The format consists of two sections i.e. Sections A comprises of Respondent's Background, and Section B is to investigate the perception on the Waste Management at Construction Site. The questionnaire focused on the obtaining the perception of the local authority, developers, contractors and others towards factors that affect sustainable construction waste management effort at site.

\subsection{Sampling}

The total population of all building contractors in Malaysia that registered in CIDB system is 124928 companies. The populations consist of contractors G1 up to G7. Table 1 shows the categorization of contractors group registered under 
CIDB. In this study, purposive sampling technique is used to determine the sample of the contractors. The technique is used to select a specific sample in a large group. In this case, the sample is all G7 building contractors. G7 contractors are chosen because of its well-known capability of financial and having good management at site. Thus they are expected to have better waste management compared to other contractors as waste management consumes high cost. The total amount of G7 contractors as recorded in CIDB are 6970. Due to lack of time and money, only several companies that are located in Kuala Lumpur, Penang, Johor Bahru and Shah Alam were randomly selected. The chosen cities are considered as they have many construction projects. Thus it is assumed that a lot of wastes are generated. Besides contractors, other parties like Government bodies, Local authorities, and Developers were also involved in the survey by using different sampling techniques namely convenience sampling technique.

Table 1: $\quad$ Grade of contractors and its limitation of tendering [8].

\begin{tabular}{|c|l|}
\hline Grade & Limitation of tendering \\
\hline G7 & No limit \\
\hline G6 & Less than RM10,000,000 \\
\hline G5 & Less than RM 5,000,000 \\
\hline G4 & Less than RM 3,000,000 \\
\hline G5 & Less than RM 1,000,000 \\
\hline G3 & Less than RM 500,000 \\
\hline G2 & Less than RM 200,000 \\
\hline G1 & Less than RM 100,000 \\
\hline
\end{tabular}

\subsection{Analysis techniques}

The data were analysed by using Relative Importance Index (RII). The calculation of the index can be obtained by using eqn (1).

$$
\text { Relative Importance Index }=\frac{\sum w}{F T}
$$

where $\mathrm{w}$ is the weighting given to each factor by the respondent, ranging from 1 to 5 in which ' 1 ' is the least important and ' 5 ' the most important; $F$ is the highest weight, in this study $\mathrm{F}=5$; $\mathrm{T}$ the total number of samples; and RII the relative important index, $0 \leq \mathrm{RII} \leq 1$.

The barriers of sustainable CWM practice at site were also analysed through correlation analysis by using Spearman's correlation test (see table 4).

\section{Results and discussions}

In order to identify the factors that affect SCWM effort at site, 95 questionnaires were sent to construction players and 30 responses were received. The distribution of the respondent can be seen in table 2 . 
Table 2: $\quad$ Distribution of survey respondents.

\begin{tabular}{lcc}
\hline Category & Number & Percentage \\
\hline Consultant & 5 & 16.67 \\
Client & 3 & 10 \\
Contractors & 21 & 70 \\
Others & 1 & 3.33 \\
\hline Total & 30 & 100 \\
\hline \hline
\end{tabular}

Table 3: $\quad$ Relative importance index for factors that affect sustainable CWM effort at site.

\begin{tabular}{|c|c|c|c|c|}
\hline Code & Factors & $\sum \mathrm{w}$ & RII & Ranking \\
\hline E1 & it affects the progress of the on-going project & 96 & 0.64 & 9 \\
\hline E2 & it consumes time & 105 & 0.7 & 5 \\
\hline E3 & it reduces the contractor's profit & 97.5 & 0.65 & 8 \\
\hline E4 & it interferes with the normal site activities & 96 & 0.64 & 9 \\
\hline E5 & lack of government enforcement & 108 & 0.72 & 3 \\
\hline E6 & $\begin{array}{l}\text { unaware of the impacts of waste on the } \\
\text { environment }\end{array}$ & 107.1 & 0.714 & 4 \\
\hline E7 & $\begin{array}{l}\text { lack of awareness to preserve natural } \\
\text { resources }\end{array}$ & 108.9 & 0.726 & 1 \\
\hline E8 & lack of training and education & 108.9 & 0.726 & 1 \\
\hline E9 & no guidelines given by Government & 93 & 0.62 & 12 \\
\hline E10 & it requires high cost & 99 & 0.66 & 7 \\
\hline E11 & $\begin{array}{l}\text { it is not as important as other activities of } \\
\text { construction management }\end{array}$ & 96 & 0.64 & 9 \\
\hline E12 & not emphasized by Management & 102 & 0.68 & 6 \\
\hline
\end{tabular}

From the result shown in table 3, "Lack of awareness to preserve natural resources" and "Lack of training and education" are considered as the major factors that affect sustainable CWM effort at site. This finding is consistent with the output of Spearman's correlation test as the correlation value between those factors is 0.699. This indicated that the factors have strong relationship. Besides that, "Lack of awareness to preserve natural resources" also has a strong relationship with "Unaware of the impact of waste on the environment". The correlation value is 0.636 . Therefore, being "unaware of the impact of waste on the environment" needs to be considered as one of the major factors as well. A contractor believed that, poor waste management gives impact not only to the environment, it also create unsafe condition. Based on the SCSA, poor housekeeping can cause accidental and near misses case at workplace. In this 


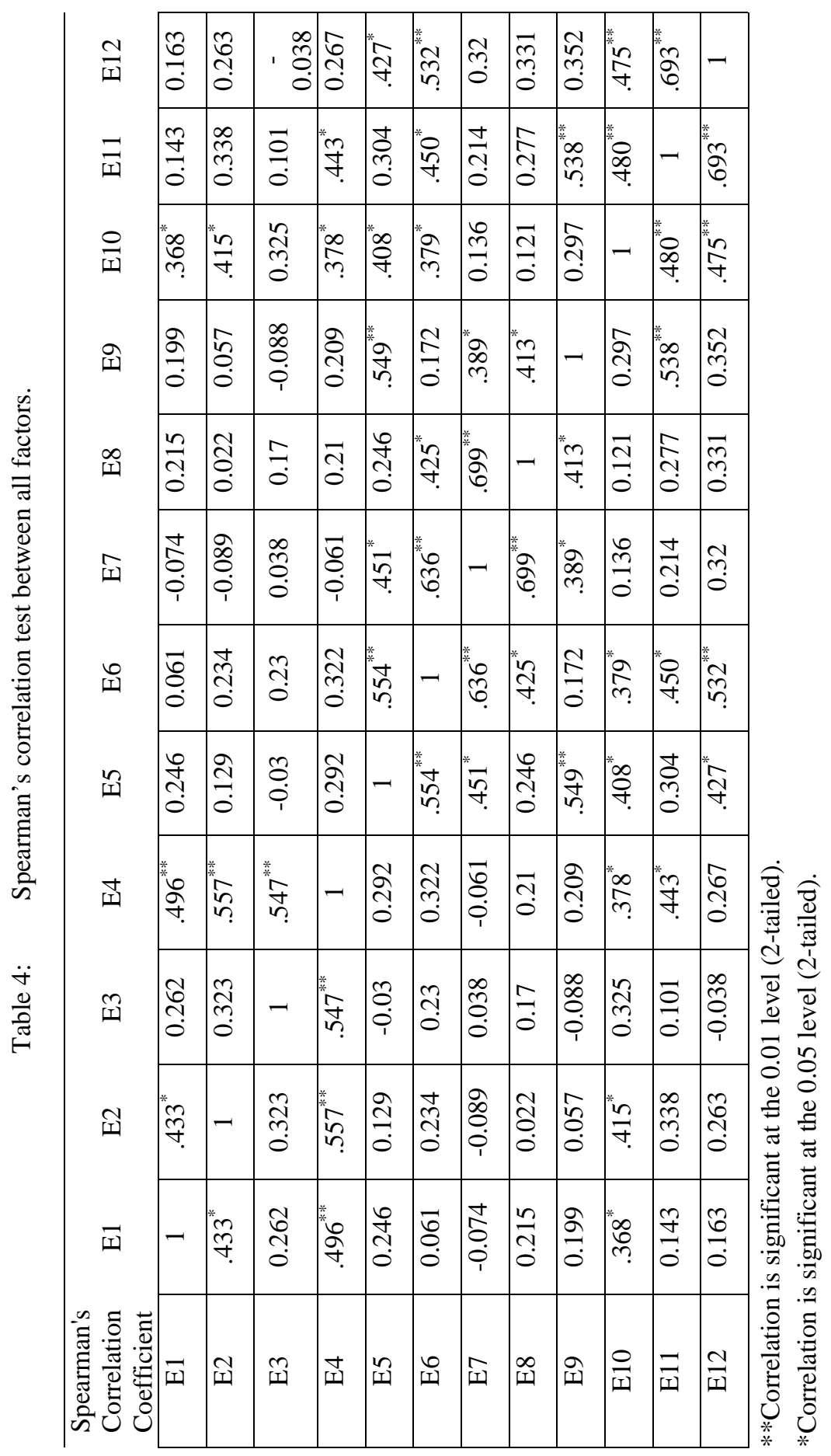


survey, the respondents also highlighted that "Lack of Government enforcement" made some contractors dare to conduct open burning at site. In addition, due to lack of enforcement, the contractors do not really concern where the waste collector dispose the construction waste. A site supervisor said that, timbers that cannot be used will be burn while others will be used for another project. In the discussion with an assistant resident engineer, he claimed that, only scrap metal will be sold while other waste material will be burn of buried at site, the reason being that the authority did not has an effective method to monitor the waste management at all project location in the country as they has insufficient staff etc.

Nevertheless, "No guideline given from the Government" is not affecting the sustainable CWM effort at site significantly. Based on the table, it is found that that the respondents did not feel that guideline on managing construction waste at site is important. In other word, they can manage the waste without a detail and specific guideline published by the authority. An assistant resident engineer said that, waste management at site is a common sense. This is because, most construction waste is inert. Thus it needs no complicated procedure to manage it

\section{Conclusions}

Management of construction waste at site in Malaysia is still not at a satisfactory standard, the reason being that construction waste are mainly disposed at landfills and burn at site. Whilst reuse and recycling activities are less practiced. This study has examined the factors that affect Sustainable Construction Waste Management at site. From the questionnaire survey, "Lack of awareness to preserve natural resources" and "Lack of training and education" are found to be major factors that hinder the contractors to implement a sustainable construction waste management at site. Based on the structured interview question, the construction players prefer a better law enforcement need to be employed by the Government and training should be provided the Government in order to educate the construction players especially building contractors. All in all, the awareness of all the construction stakeholders will determine the level of the implementation.

\section{Acknowledgements}

A special thanks to all construction companies, developers and consultants that were involved in this study and shared their opinions and information on the research topic.

\section{References}

[1] Kulatanga, U., Amaratunga, D., Haigh, R. and Rameezden, R., Attitudes and perceptions of construction workforce on construction waste in Sri Lanka, Management of Environment Quality, 17(1), pp. 57-72, 2006. 
[2] Ya’cob, A.S., Wan Abdullah Zawawi, W.N.A., Isa, M.H., and Othman, I., Effective Waste Management Practice on Construction Site, presented at the Engineering, Science and Technology Congress, Kuala Lumpur, KL, 2012.

[3] Begum R.A., Siwar, C., Pereira, J.J., and Jaafar A.H., A benefit-cost on the economic feasibility of construction waste minimization: the case of Malaysia. Resources, Conservation and Recycling, 48(1), pp. 86-98, 2006.

[4] Tam, V.W.Y., On the effectiveness in implementing a waste-managementplan method in construction. Waste Management, 28(6), pp. 1072-1080, 2007.

[5] Papargyropolou E., Preece C., Padfield R., Abdullah A. A., Sustainable Construction Waste Management in Malaysia: A Contractor's perspective, Proc. in the Int. Conf. of Management and Innovation for a Sustainable Built Environment, ISBN: 9789052693958, 2011.

[6] Abdullah A., A Methodological Analysis in Demolition Works in Malaysia, Pusat Pengurusan Penyelidikan UTM, JB, Malaysia, 2008.

[7] Saskatchewan Construction Safety Association (SCSA), www.scsaonline.ca

[8] Construction Industry Development Board, www.cidb.gov.my 